\title{
The Knowledge and Attitudes of Nursing Students Infertility and Determination of Factors Affecting These Variables
}

\section{Hemşirelik Öğrencilerinin İnfertiliteye İlişkin Bilgi Düzeyleri, Tutumları ve Etkili Faktörlerin Belirlenmesi}

\author{
Çiler Çokan Dönmez ${ }^{1}$ (iD) Tuba Güner Emül ${ }^{2}$ iD \\ ${ }^{1}$ Adana Balcalı Hospital, Adana, TURKEY \\ ${ }^{2}$ Mersin University Faculty of Nursing, Mersin, TURKEY \\ Geliș tarihi/ Date of receipt: 28/04/2021 \\ Kabul tarihi/ Date of acceptance: 12/08/2021 \\ (C) Ordu University Faculty of Health Sciences, Department of Nursing, Turkey, Published online: 26/12/2021
}

\begin{abstract}
Objective: This study aims to determine the nursing students knowledge levels, attitudes and related factors about infertility. Methods: The research sample consisted of 550 nursing students studying at a state university in the south of Turkey between December 2019 -March 2020. The Introductory Information Form of the students, "Infertility Knowledge Test" and "Attitude Scale Towards Infertility" were collected in connection with the research. The obtained data were evaluated using percentage values, Student's t-test, Tukey and ANOVA tests.

Results: The mean age of the students was $21.15 \pm 1.99$. It was determined that $28.4 \%$ of the students were educated in the third grade, 58.4\% were women and 67.8\% were born in the Southern Anatolia Region. In the study, it was determined that the total mean scores of the Infertility Knowledge Test of the nursing students were "19.23 \pm 6.48 "( $\min =0$ - $\max =31)$, and the total mean score of the Attitude Scale towards Infertility was $46.00 \pm 7.5(\mathrm{~min}=16$ - $\max =60)$, The difference between the mean scores of the Infertility Knowledge Test was found to be statistically significant according to the class of the students, their region of birth, being an infertile individual in the family and having children in the future $(\mathrm{p}<0.05)$. A statistically significant difference was found between the students' grades of education and gender, the region they were born, the place of residence, and the mean scores of the Attitudes Towards Infertility Scale $(\mathrm{p}<0.05)$.

Conclusion: In conclusion, it was confirmed that the nursing students have good knowledge about infertility and their attitudes towards infertility are positive.
\end{abstract}

Keywords: Infertility, nursing students, knowledge level, attitude

ÖZ

Amaç: $\mathrm{Bu}$ araştırmanın amacı, hemşirelik öğrencilerinin infertiliteye ilişkin bilgi düzeylerinin, tutumlarının ve ilişkili faktörlerin belirlenmesidir

Yöntem: Araştırma örneklemini, Aralık 2019-Mart 2020 tarihleri arasında Türkiye'nin güneyinde bir devlet üniversitesinde öğrenim gören 550 hemşirelik öğrencisi oluşturdu. Araştırmanın verileri, öğrencilerinin kişisel özelliklerini tespit etmeye yönelik Tanıtıcı Bilgi Formu, "İnfertilite Bilgi Testi" ve "İnfertiliteye Yönelik Tutum Ölçeği" kullanılarak toplandı. Elde edilen veriler yüzde değerler, Student's t-test, Tukey and ANOVA test kullanılarak değerlendirildi.

Bulgular: Araştırmada hemşirelik öğrencilerinin yaş ortalamaları $21.15 \pm 1.99$ 'dur. Öğrencilerin \%28.4'ünün üçüncü sınıfta öğrenim gördüğü, \%58.4'ünün kadın olduğu ve \%67.8'inin Güneydoğu Anadolu Bölgesinde doğduğu belirlendi. Araştırmada hemşirelik öğrencilerinin İnfertilite Bilgi Testi toplam puan ortalamalarının " $19.23 \pm 6.48$ ” (min=0- $\max =31)$, İnfertiliteye Yönelik Tutum Ölçeği toplam puan ortalamalarının " $46.00 \pm 7.59$ " $(\min =16-\max =60)$ olduğu saptandı. Öğrencilerinin sınıfları, doğdukları bölgeler, ailede infertil birey olma ve gelecekte çocuk sahibi olma durumlarına göre İnfertilite Bilgi Testi puan ortalamaları arasındaki fark istatistiksel olarak anlamlı bulundu $(\mathrm{p}<0.05)$. Öğrencilerinin öğrenim gördükleri sınıfları ve cinsiyetleri, doğdukları bölge, yaşanılan yer ile İnfertiliteye Yönelik Tutum Ölçeği puan ortalamaları arasında istatistiksel olarak anlamlı fark bulundu $(\mathrm{p}<0.05)$.

Sonuç: Araştırmada, hemşirelik öğrencilerinin infertilite ile ilgili bilgi düzeyinin iyi olduğu ve infertiliteye yönelik tutumlarının olumlu olduğu belirlendi.

Anahtar Kelimeler: İnfertilite, hemşirelik öğrencileri, bilgi düzeyi, tutum

ORCID IDs of the authors: ÇÇD: 0000-0001-8706-3685; TGE: 0000-0002-6284-9419

Sorumlu yazar/Corresponding author: Tuba Güner Emül, $\mathrm{PhD}$

Mersin University Nursing Faculty, Mersin, TURKEY

e-posta/e-mail: tubaguner2007@gmail.com

Atıf/Citation: Dönmez ÇÇ, Emül TG. (2021). The knowledge and attitudes of nursing students infertility and determination of factors affecting these variables. Ordu Üniversitesi Hemşirelik Çalışmaları Dergisi. 4(3), 375-381. DOI: 10.38108/ouhcd.929199 


\section{Introduction}

Infertility is the inability of a couple to achieve pregnancy over an average period of one year (in a woman under 35 years of age) or 6 months (in a woman above 35 years of age) despite adequate, regular (3-4 times per week), unprotected sexual intercourse (Beji, 2015; Cooper et al., 2010; Taşkın, 2016). According to the data of the World Health Organization-World Health Organization (WHO) it is estimated that more than 80 million people worldwide are affected by infertility (WHO, 2020). About $9 \%$ of men and $10 \%$ of women aged 15 to 44 reported infertility problems in the United States (CDC, 2013; Office on Women's Health, 2019). It was determined that in Turkey, the rate of childless and infertile married women between the ages of 15 and 49 is $11.2 \%$ (TNSA, 2013).

Infertility is a sensitive case for which couples need the help of healthcare professionals who have the necessary knowledge, as well as the supporting and empathic approach. Nurses, who are the first healthcare professionals with whom couples communicate during and after the treatment, play a very important role in the coordination of the different stages of the treatment and in ensuring couples' commitment to the treatment (Beji, 2015; Çakır et al., 2020; Karaca and Ünsal, 2012). Attitudes of nurses can affect their perspectives, professional attitudes, and roles. Nurses must be aware of their own feelings about infertility and keep these emotions under control to be able to help infertile couples. Nurses exhibiting a positive attitude resulting from their knowledge can reduce the physiological, emotional, psychological, sexual problems and social negativities infertile couples experience because of infertility (Ali et al., 2011; Çağlar and Oskay, 2020; Çakır et al.,2020; Erbil et al., 2010; Hammarberg et al., 2013; Karaca and Ünsal, 2012). It is crucial for nurses to plan and implement their nursing approaches after they identify their own knowledge levels and attitudes, upon graduation and before they start their professional careers so that they can provide positive care and counseling services to infertile couples.

When the literature was examined during the planning and writing stages of this study, no studies were found to determine the knowledge and attitudes of nursing students about infertility. In this context, it is thought that identifying the knowledge levels and attitudes of nursing students towards infertility, addressing the social, religious, and psychosocial dimensions of infertility, and making relevant changes in the curriculum will make important contributions to the field. In addition, knowing the knowledge of future parents about infertility will also contribute to raising awareness in terms of fertility awareness. This study was conducted to identify the knowledge levels and attitudes of nursing students regarding infertility and factors affecting these variables.

\section{Research Questions}

1. What are the knowledge levels of nursing students about infertility?

2. What are the nursing students' attitudes towards infertility?

3. What are the factors affecting students' knowledge and attitudes towards infertility?

\section{Material and Method}

This study used a descriptive and cross-sectional research design. This study was conducted to identify determine the levels of knowledge and attitudes of nursing students towards infertility, as well as the factors affecting these variables. The study was conducted between December 2019 and March 2020, and the population of the study consists of 750 nursing students. Aiming to work with all participants, no sampling was made in this study. Accordingly, the final number of participants of the study was 550 after the participants who did not agree to participate in the study, did not complete the questionnaires, and did not attend their classes were excluded. $73 \%$ of the participants were reached. The data of the study were collected by using the Questionnaire Form aimed at determining the personal characteristics of nursing students, as well as the "Infertility Knowledge Test" and "Attitude towards Infertility Scale". The questionnaire form was prepared by the researchers after a literature review was made on the subject (Ali et al., 2011; Beji, 2015; Erbil et al., 2010; Hammarberg et al., 2013; Karaca and Ünsal, 2012; Taşkın, 2016). The questionnaire form consists of two different sections. The questionnaire form consists of a total of five questions, the first part of which consists of five questions about the personal characteristics of nursing students (age, gender, class etc.), and the second part of which consists of five questions about infertility.

\section{Data Collecting Instrument \\ Infertility Knowledge Test}

Infertility Knowledge Test (IKT), developed by Siyez et al. In 2018, consists of 33 items. The response format of the test was arranged as "Right", "False" and "I don't know". Nineteen of the items in 
the test are coded straight and 14 of them are coded reverse. Reverse coded items are 2, 3, 10, 17, 18, 19, 20, 21, 22, 23, 24, 25, 27 and 32. Participants get one point for each question for the correct answer. High scores from the test indicates that their knowledge of infertility is high. The average difficulty and KR20 reliability coefficient of the test were calculated within the scope of the validity and reliability study of the IKT.

\section{Attitude Scale Towards Infertility}

The Attitude Scale towards Infertility, developed by Siyez et al. In 2018, consists of 12 items. The response format of the scale was arranged in a fivepoint likert structure as "(1) I never agree, (2) I do not agree, (3) I am not sure, (4) I agree, (5) I completely agree". Items number 1, 2, 5, 6, 8, 9, 11 and 12 in the scale are scored in reverse. The highest score to be obtained from the scale is 60 and the lowest score is 12 . High scores of the scale indicates a positive attitude towards infertility. Siyez et al. (2018) reported the Cronbach alpha coefficient of the scale as 0.89 . In our study, the Cronbach alpha coefficient was calculated as 0.84 .

\section{Statistical Analyses}

The data were analyzed using SPSS V 20 software. Prerequisites such as variables, homogeneity of variances, and normality were evaluated using Shapiro-Wilk test and Levene's test. Two groups were compared using the Student's ttest and three or more groups were compared using the Tukey and ANOVA test. The value of $p<0.05$ was accepted for the significance level of the tests. Frequency, percentage, median (maximumminimum), mean, and standard deviation values were used as descriptive statistics.

\section{Results}

The average age of nursing students was found to be $21.15 \pm 1.99$. When the table is examined, it can be seen that $28.4 \%$ of the students are third-grade students and more than half (58.9\%) of them are women. It was determined that $67.8 \%$ of the nursing students were born in the South Anatolian Region and nearly half $(47.6 \%)$ lived in the city center. $88.4 \%$ of the students stated that they would like to have children in the future, $78.9 \%$ of them do not have an infertile individual in their family, and $37.5 \%$ of them took a course on infertility.

When the table is examined, it can be seen that the students scored a minimum of " 0 " and a maximum of 31 points from the Infertility Knowledge Test. The total IKT score average of the nursing students was found to be "19.23 $\pm 6.48 "$.
When the table is examined, it is seen that students scored a minimum of "16" and a maximum of "60" points from the Attitude towards Infertility Scale. The total average ATIS score of the nursing students was found to be $46.00 \pm 7.59$ (Table 1).

Table 1. The Infertility Knowledge Test and Attitudes Towards Infertility Scale of Nursing Students (n: 550)

\begin{tabular}{lcccc}
\hline & $\mathbf{n}$ & $\overline{\mathbf{X}} \pm \mathbf{S S}$ & Min & Max \\
\hline $\begin{array}{l}\text { IKT Total } \\
\text { Point }\end{array}$ & 550 & $19.23 \pm 6.48$ & 0 & 31 \\
$\begin{array}{l}\text { ATIS Total } \\
\text { Point }\end{array}$ & 550 & $46.00 \pm 7.59$ & 16 & 60 \\
\hline
\end{tabular}

It has been determined that the IKT score averages of the participants significantly differ by the region where they were born and that the participants born in Central Anatolia and Western Anatolia regions scored higher than those born in other regions $(p<0.05)$. The table shows that there is a statistically significant difference between the IKT scores of the participants, who differ in terms of wanting to have children in the future, having an infertile family member, and taking a class on infertility $(\mathrm{p}<0.05)($ Table 2$)$. It has been determined that the IKT score averages of the participants who want to have children in the future, who have an infertile family member, and who took a class on infertility are higher than the participants who do not want to have children in the future, who do not have an infertile family member, and who did not take a class on infertility.

When the table is examined, it can be seen that the difference between the average Attitudes Towards Infertility Scale (ATIS) scores of nursing students by their class, gender, place of birth, and longest residence is statistically significant $(p<0.05)$ (Table 2). It has been determined that the difference between the average ATIS scores of the participants by their semesters is statistically significant, and the fourth-year students have lower ATIS scores than earlier year students $(\mathrm{p}<0.05)$

When the table is examined, it can be seen that the difference between the average ATIS scores of the students statistically differed by gender, and the average ATIS scores of female students are higher than those of male students $(\mathrm{p}<0.05)$. 
Table 2. Comparison of IKT and ATIS Scores of Nursing Students According to Their Characteristics (n: 550)

\begin{tabular}{|c|c|c|c|c|c|}
\hline & & IKT & & ATIS & \\
\hline Characteristics & $\mathbf{n}$ & $\overline{\mathbf{X}} \pm \mathbf{S S}$ & $\mathbf{p}$ & $\overline{\mathbf{X}} \pm \mathbf{S S}$ & p \\
\hline \multicolumn{6}{|l|}{ Grade } \\
\hline First Grade & 130 & $14.71 \pm 6.05$ & \multirow[t]{4}{*}{$<0.001 * *$} & $46.27 \pm 7.95$ & \multirow[t]{4}{*}{$<0.001 * *$} \\
\hline Second Grade & 121 & $16.89 \pm 5.50$ & & $47.46 \pm 6.59$ & \\
\hline Third Grade & 156 & $21.99 \pm 4.70$ & & $46.78 \pm 7.77$ & \\
\hline Forth Grade & 143 & $22.30 \pm 6.17$ & & $43.67 \pm 7.41$ & \\
\hline \multicolumn{6}{|l|}{ Gender } \\
\hline Female & 324 & $18.92 \pm 6.31$ & \multirow[t]{2}{*}{$0.189 *$} & $46.80 \pm 7.33$ & \multirow[t]{2}{*}{ 0.003* } \\
\hline Male & 226 & $19.66 \pm 6.70$ & & $44.85 \pm 7.82$ & \\
\hline \multicolumn{6}{|l|}{ Birthplace } \\
\hline Western Anatolia region & 28 & $20.39 \pm 6.66$ & \multirow{5}{*}{$<0.001 * *$} & $48.71 \pm 7.59$ & \multirow{5}{*}{$<0.001 * *$} \\
\hline Central Anatolia region & 41 & $21.39 \pm 5.72$ & & $46.68 \pm 7.84$ & \\
\hline North Anatolian region & 17 & $15.11 \pm 7.85$ & & $42.64 \pm 6.48$ & \\
\hline Southern Anatolian region & 373 & $19.55 \pm 6.13$ & & $46.62 \pm 7.56$ & \\
\hline Eastern Anatolia region & 91 & $17.36 \pm 7.22$ & & $42.95 \pm 6.92$ & \\
\hline \multicolumn{6}{|l|}{ Residence place of family } \\
\hline City Center & 262 & $19.45 \pm 6.00$ & \multirow[t]{3}{*}{$0.718 * *$} & $46.82 \pm 7.63$ & \multirow[t]{3}{*}{$0.036 * *$} \\
\hline Countryside & 208 & $19.08 \pm 7.32$ & & $45.51 \pm 7.25$ & \\
\hline Village & 80 & $18.87 \pm 5.65$ & & $44.60 \pm 8.11$ & \\
\hline \multicolumn{6}{|l|}{$\begin{array}{l}\text { Desire to have children in } \\
\text { the future }\end{array}$} \\
\hline Want & 486 & $19.41 \pm 6.58$ & \multirow[t]{2}{*}{0.035} & $45.89 \pm 7.41$ & \multirow[t]{2}{*}{$0.365^{* *}$} \\
\hline Not want & 64 & $17.81 \pm 5.51$ & & $46.81 \pm 8.89$ & \\
\hline \multicolumn{6}{|l|}{$\begin{array}{l}\text { The presence of an } \\
\text { infertile person in the } \\
\text { family }\end{array}$} \\
\hline Yes & 116 & $20.59 \pm 6.25$ & \multirow[t]{2}{*}{ 0.012* } & $46.11 \pm 8.00$ & \multirow[t]{2}{*}{$0.863^{*}$} \\
\hline No & 434 & $18.87 \pm 6.50$ & & $45.97 \pm 7.49$ & \\
\hline \multicolumn{6}{|l|}{ Took infertility lessons } \\
\hline Yes & 206 & $23.04 \pm 4.30$ & \multirow[t]{2}{*}{$<0.001 *$} & $45.94 \pm 7.77$ & \multirow[t]{2}{*}{0.892} \\
\hline No & 344 & $16.94 \pm 6.49$ & & $46.03 \pm 7.50$ & \\
\hline
\end{tabular}

* Student's t Test ** One-way variance analysis *** Tukey Test

It has been determined that the difference between the average ATIS scores of the participants by their places of birth is statistically significant and that the average ATIS scores of the participants born in the Western Anatolia Region are higher than those born in other regions $(p<0.05)$. It has been determined that the difference between the average ATIS scores of the participants by their places of longest residence is statistically significant and that the average ATIS scores of the participants who live in the city center are higher than those who do not $(\mathrm{p}<0.05)$.
No statistically significant difference has been determined between average ATIS scores and wanting to have children in the future, having an infertile family member, and taking a class on infertility $(p>0.05)$.

It has been determined that there was no statistically significant relationship between the nursing students' IKT scores and ATIS scores $(\mathrm{r}=$ $0.075 ; p=0.079$ ). It has been determined that there was a weak, positively significant correlation between the ages of nursing students and their ATIS scores $(\mathrm{r}=0.348 ; \mathrm{p}<0.001)$, and a very weak, negatively significant correlation between the ages 
of nursing students and their IKT scores $(\mathrm{r}=-0.115$; $\mathrm{p}=0.007)$. When the findings of the study are examined in terms of the age variable, it has been detected that as the older nursing students are, the more they know they know about infertility and that the age factor has a very weak and negatively significant relationship with attitudes towards infertility.

\section{Discussion}

It is very important that the nurses and nursing students have sufficient knowledge and develop their awareness regarding this condition. The this was found that the average score the nursing students got from the infertility knowledge test is $19.23 \pm 6.48$. In a similar study by Taşçı and Özkan (2007), it was determined that nursing students do not have sufficient knowledge about infertility. In a study conducted by Küçükkaya et al. (2018) with nursing students, it was found that students were knowledgeable about fertility. The study conducted by Ashley Thomson et al. (2016) concluded that medical students have a good level of infertility knowledge. In their study that investigated the knowledge levels of university students on infertility, Siyez et al. (2018) concluded that university students had insufficient knowledge of infertility. Comparing our study and other studies in the literature, it has been determined that the nursing students who participated in our study are more knowledgeable on infertility than the participants of other studies. This may be due to the participants gaining knowledge on the topic after the pieces of training and the lessons they have taken in recent years on the protection of reproductive health and fertility.

Attitudes may affect individuals' perspectives, professional attitudes, and roles. The positive attitude of nursing students as healthcare workers towards infertility after they graduate plays an important role in terms of the needs of infertile individuals (Erbil et al., 2010; Karaca and Ünsal, 2012). Since infertility is not only a health problem but can also be regarded as a social problem, it is thought that identifying and improving the nursing students' attitudes towards infertility can contribute to the solution of such social problems. In our study, the average attitude towards infertility scale scores of the nursing students was found to be $46.00 \pm 7.59$. In a study conducted by Yilmaz (2020) with nursing students, it was found that the average of students' attitude towards infertility scale scores was $44.24 \pm$ 7.66. In a study conducted by Koropeckyj and Çopur
(2015) with American and Turkish university students, it was found that the attitudes of students towards infertility were positive, but the attitudes of Turkish students were relatively more positive. Taşçı and Özkan (2007) examined the perceptions of health school students about infertility and found that students who were male and wanted to have children in the future had relatively more negative perceptions of being infertile. Çakır et al. (2020) in their study, it was determined that midwifery and nursing students had a positive attitude towards infertility. Comparing our study and other studies in the literature, it has been determined that the nursing students who participated in our study have more positive perceptions of infertility than the participants of other studies. Considering that not being able to have children is perceived as a deficiency in Turkey and that there exists a social pressure to have children, this finding is an important and pleasing one.

A statistically significant difference has been found between the IKT scores of nursing students by their classes $(p<0.05)$. It has been determined that the average IKT scores of the fourth-year students are higher than the average IKT scores of other year students. This can be explained by the fact that fourth-year nursing students take classes on obstetrics and gynecology nursing and infertility nursing. It can be suggested that as the level of education increases, the level of knowledge and awareness on the topic and increases as well, which positively contributes to the students' perceptions of infertility.

It has been determined that the difference between the average IKT scores of the participants by their places of birth is statistically significant and that the average IKT scores of the participants born in the Central Anatolia and Western Anatolia regions were higher than those born in other regions $(\mathrm{p}<0.05)$. This can be explained by the fact that infertility can be more comfortably discussed in the central and western parts of the country.

A statistically significant difference has been detected between the average IKT scores and levels of nursing students' desire to have children in the future and it has been determined that the average of the IKT scores of the students who want to have children in the future is higher than those of the students who do not want to have children in the future $(\mathrm{p}<0.05)$. Contrary to our study, Siyez et al. (2018) found that students who do not want to have children in the future have a higher level of knowledge on infertility than the students who do. 
In line with these results, the participants who study nursing and want to have children in the future having more knowledge on infertility may be because of the fact that they are studying nursing.

A statistically significant difference has been detected between the average IKT scores and having an infertile family member and it has been determined that the average of the IKT scores of the students who have infertile family members is higher than those of the students who do not have infertile family members $(p<0.05)$. Similarly, Siyez et al. (2018) found that university students who knew people with infertility problems had higher levels of knowledge about infertility than those who did not, and their attitudes towards infertility were more positive. This shows a similarity to the findings of our study. This can be explained by the fact that the people who have an infertile family member witness the difficulties experienced during the diagnosis and treatment processes, as well as possible risks such as failed treatment.

A statistically significant difference has been detected between the average IKT scores and whether nursing students took a class on infertility and it has been determined that the average of the IKT scores of the students who did take a class on infertility is higher than those of the students who did not $(\mathrm{p}<0.05)$. This was an expected outcome. It is natural to think that taking a class on infertility increased the level of knowledge and awareness of nursing students on this topic.

It has been determined that the average ATIS scores of female participants are comparatively higher than those of male participants. It has been found in our study that the perception of female participants towards infertility is more positive than those of male participants. In the study they conducted to determine the opinions of health faculty students about infertility, Taşçı and Özkan (2007) found that female students' views on infertility were more positive than male student. In a similar study conducted by Y1lmaz (2020), it was determined that the attitudes of male students towards infertility were relatively more negative and they had lower empathy levels compared to female students. This situation can be explained by the fact that men have a more negative attitude towards infertility since they see having children as a continuation of their ancestry.

When the ATIS scores of the nursing students who participated in our study were compared by their semester, it was found that the ATIS scores of the fourth-year students were significantly higher than the students of other years. In a study conducted by Yağmur and Oltuluoğlu (2012) found in their study that the education level of infertile women affected the level of despair and that the level of despair of primary school graduates was higher and that of university graduates was lower. This can be explained by the increase in education level. It has been determined that the difference between the average ATIS scores of the participants by their places of birth is statistically significant and that the average ATIS scores of the participants born in the Eastern Anatolian Region were lower than those born in the Western and Southern Anatolian regions $(\mathrm{p}<0.05)$. It has been determined that the difference between the average ATIS scores of the participants by their places of longest residence is statistically significant and that the average ATIS scores of the participants who lived in villages for the longest were lower than those who lived in the city and districts for the longest $(\mathrm{p}<0.05)$. This may be due to socio-cultural differences and ease of access to technology.

When the findings of the study are examined in terms of the age variable, it has been detected that as the older nursing students are, the more they know they know about infertility and that the age factor has a very weak and negatively significant relationship with attitudes towards infertility. This may be because the ages of the students and their level of education are directly proportional.

\section{Conclusion and Recommendations}

In this study, it was determined, that the nursing students have good knowledge about infertility and their attitudes towards infertility are positive. It can be recommended to carry out in-depth studies by conducting qualitative studies to determine the attitudes of nursing students about infertility, to carry out studies with large samples on the factors affecting the views of nursing students about infertility, to conduct the research in a larger sample group, and to conduct knowledge and attitude studies towards nurses.

\section{Limitations of the Study}

The sample of the study is limited to the third and fourth year students of Mersin University School of Health and the first and second year students of Mersin University Nursing Faculty. The study is based on the reports of the participants.

\section{Acknowledgments}

The authors would like to thank all the students. 
Ethics Committee Approval: Before the questionnaire was applied, institutional permissions were obtained from Toros Scientific Research and Publication Ethics Committee with the decision dated 27/12/2019 and numbered 2020/113. At each step of the research, the principles of the Declaration of Helsinki were followed.

Peer-review: External referee evaluation.

Author Contributions: Concept: ÇÇD, TGE; Design: ÇÇD; Supervision: TGE; Data Collect ÇÇD; Data Processing: ÇÇD; Analysis and Interpretation: ÇÇD, TGE; Literature Search: CÇD, TGE; Preparation of the manuscript: ÇÇD, TGE; Critical Reviews: ÇÇD, TGE.

Conflict of interest: The authors declared no potential conflicts of interest with respect to the research, authorship, and/or publication of this article.

Financial Disclosure: The authors did not receive any financial support in conducting this study.

\section{What did the study add to the literature?}

- It is thought that determining the knowledge, attitudes and influencing factors on the subject before starting the professional career of the students who receive nursing education will contribute to the social, religious and psychosocial dimensions of infertility and to make arrangements regarding this subject in the curriculum.

- It is important in terms of being a source and contributing to future studies.

\section{References}

Ali S, Sophie R, Imam, AM, Khan FI, Ali SF, Shaikh A, Farid HS. (2011). Knowledge, perceptions and myths regarding infertility among selected adult population in Pakistan: A cross-sectional study. BMC Public Health, 11(1), 760-766.

Ashley A, Thomson MD, Meghan B, Shannon Z, Emily S, Philip M, Hahn RLR. (2016). Evaluating acquisition of knowledge about infertility using a whiteboard video. Journal of Obstetrics and Gynecology Canada, 38(7), 646-650.

Assisted Reproductive Technology Fertility Clinic Success Rates Report (2013) 27.07.2021 tarihinde https://www.cdc.gov/art/pdf/2013-report/art-2013fertility-clinic-report.pdf ulaşı1mıştır.

Beji, NK. (2015) Women's Health and Diseases. 1. Bask1, İstanbul, Nobel Tip Kitapevi, pp: 113-118.

Cooper TG, Noonan E, Eckardstein S. (2010). World Health Organization reference values for human semen characteristics. Human Reproduction Update, 16 (3), 231-245.

Çağlar M, Oskay YÜ. (2020). Infertility and effects on sexual Life. JAREN, 6(1),157-162

Çakır D, Dağlar G., Bilgiç D. (2020). Determination of the department of nursing and midwifery students

Erbil N, Bostan Ö, Kahraman AN. (2010). Hopelessness among infertile women and men. Turkiye Klinikleri
Journal of Gynecology and Obstetrics, 20(4), 228235.

Hacettepe University Institute of Population Studies (2013). Turkey Demographic and Health Survey. Ankara, Hacettepe University Institute of Population Studies.

Hammarberg K, Setter T, Norman RJ, Holden CA, Michelmore J, Johnson L. (2013). Knowledge about factors that influence fertility among Australians of reproductive age: A population-based survey. Fertility and Sterility, 99(2), 502-507.

Karaca A, Ünsal G. (2012). The Effects of infertility on women's mental health and role of psychiatric nursing. Journal of Psychiatric Nursing, 3(2), 80-5.

Koropeckyj T, Çopur Z. (2015). Attitudes about childlessness and infertility treatments: A comparison of Turkish and American University students. Journal of comparative family studies, 46(3), 373-402.

Küçükkaya B, Süt HK, Koyunoğlu Y, Kaya M, Yonğaç C. (2018). The knowledge and attitudes of nursing students about the factors affecting fertility. SAUHSD, 1(1), 52-64.

Office on Women's Health (2019) 27.07.2021 tarihinde https://www.womenshealth.gov/a-z-topics/infertility ulaşılmıştır.

Özçelik B, Karamustafalığlu O, Özçelik A. (2007). Psychological and psychiatric aspects of infertility. Anatolian Journal of Psychiatry, 8(2), 140-148.

Siyez DM, Baran B, Kağnıcı DY, Esen E. (2018). Examining the knowledge and attitudes of university students about infertility and evaluating the effectiveness of infertility prevention psychoeducation program and online education program. TÜBİTAK SOBAG 215K001 Proje Sonuç Raporu. İzmir.

Siyez DM, Esen E, Baran B, Seymenler S, Kağnıcı DY, Siyez E. (2018). Development of the attitudes toward infertility scale (ATIS): validity and reliability study. Cukurova Medical Journal, 43(1), 173-180.

Taşçı TK, Özkan S. (2007). University school for health sciences students' opinions about infertility. TAF Preventive Medicine Bulletin, 6(3), 1-7.

Taşkın L. (2016). Obstetrics and women's health nursing. Ankara, Akademisyen Kitapevi, pp.647-669

Yağmur Y, Oltuluoğlu H. (2012). Social support and hopelessness in women undergoing infertility treatment in eastern Turkey. Public Health Nursing, 29, 99-104.

Yilmaz E. (2020). Attitudes toward infertility and empathy levels of nursing students. Turkiye Klinikleri Journal of Nursing Sciences, 12(2), 236243.

World Health Organization. Sexual and reproductive health: Infertility is a global public health issue. Erişim tarihi: 29.11.2020 https://www.wheo.int/reproductivhealth/topics/ infertility/perspective/en/ 